\title{
Hybrid Venture Capital Funds in Lithuania: Motives, Factors and Present State of Development
}

\section{Vytautas Snieska, Vitalija Venckuviene}

\author{
Kaunas University of Technology \\ Laisves av. 55-506, LT-44309 Kaunas, Lithuania \\ e-mail:vytautas.snieska@ktu.lt,vitalija.venckuviene@stud.ktu.lt \\ crossref http://dx.doi.org/10.5755/j01.ee.22.2.312
}

Substantial body of academic literature agree that the financial constrain is the core problem in developing early stage small and medium sized enterprises (SMEs). Therefore, venture capital through financing and providing value added services is considered to be an effective tool in increasing regions innovation capacity, fostering economic growth as well as job creation. Thus, financing such promising young ventures, especially those with technological background, is encouraged in many countries through various Governments' initiatives.

A wide range of research explores public programmes in enhancing venture capital markets development in various countries either through direct (when Government invest directly in fund) or indirect (for instance, tax relief, etc.) measures. Therefore the present paper focuses on the direct Government intervention in venture capital market development, through investing in venture capital funds (as the co-investor or limited partner) in order to facilitate SMEs through financing its early stage of development. Venture capital funds, pooled by Governments' sources, private and institutional investors, aiming to boost investments in early stage innovative companies, are considered as hybrid venture capital funds in this paper.

The article deals with the development of hybrid venture capital funds in Lithuania, which were forced by the European Union (EU) initiative Joint European Resources for Micro to Medium Enterprises (JEREMIE) seeking to increase access to finance the development of SMEs through facilitation of venture capital markets development in various EU regions.

There is lack of research focusing on the factors for efficient public policy intervention in the developing hybrid venture capital funds in order to facilitate early stage SMEs. Thus, the problem of the paper covers the question: what are the motives, factors and present state of development of hybrid venture capital funds in Lithuania.

The present paper will explore the Government's initiative in Lithuania in terms of JEREMIE initiative. Therefore the paper aims to contribute to research dealing with hybrid venture capital funds' role in boosting regional economies through the financing the SMEs in their early stage of development.

The paper finds that Lithuanian venture capital market is in its infant stage, and the Governments' initiative towards creation hybrid venture capital funds definitely will increase the investments in SMEs. Moreover, supplyside, demand-side and macroeconomic factors should be taken into account in the venture capital markets development. And still cautious actions should be set along with the public initiative in order to overcome the negative aspects of venture capital investments, such as lack of transparency, money laundering, etc.

Keywords: Hybrid venture capital fund, small and medium sized enterprises, European Union support, JEREMIE initiative.

\section{Introduction}

SMEs have a significant attention in many countries' policies as it is considered to be an engine for Economic prosperity. Lack of asset, liquidity, information asymmetries are among the focal problems which early stage business encounter with (Sahlman, 1990). Thus, it is the main reason why banks' loans are not acquirable in this stage of the SMEs development. Therefore venture capital through provision of capital and other value added services plays a significant role in fostering economic growth.

Many scientists agree that Government can foster the economy by creating efficient frameworks for venture capital support (Cumming, 2007; del-Palacio, Zhang, \& Sole, 2010), despite that, there are controversial opinions too. Some studies conclude that the Governments' intervention in venture capital market should be considered more cautiously in terms of facilitating SMEs, not the venture capitalists (Florida \& Smith, 1993; Lerner, 2010).

Despite of many researches in the field of venture capital, there is no unique definition of venture capital. Some studies (for example prepared by European Private Equity and Venture Capital Association - EVCA) the terms 'private equity' and 'venture capital' use interchangeably. The differences between these two terms are significant in the context of the United States (US), because in this perspective, the venture capital refers to equity investments in start-up and early stage investment in private companies, and private equity investments cover later stage investments and buyouts (Cowling et al., 2008; Plage, 2006). Thus, in this article we refer to venture capital investments as a part of private equity investments.

In the context of recent recession, the private equity investment is slightly going up, since the sharp decrease in the third quarter (Q) of 2008. EVCA Quarterly Activity Indicator Q2 2010 depicts that European private equity investments increased in 16 percent, despite that it is still far from the 2007 peak. Meanwhile, the indicator of funds raised remained low and reached the level of Q4 of 2009 (PEREP_Analytics ${ }^{\mathrm{TM}}$, 2010). Therefore Government could play an important role in facilitating SMEs through the investments in venture capital funds. 
Governments' intervention in venture capital market was analyzed by many scientists (Bottazzi \& Da Rin, 2002; Cumming, 2007; Cumming \& Johan, 2009; Da Rin, Nicodano, \& Sembenelli, 2006; Jääskeläinen, Maula, \& Murray, 2007; Lerner, 2001, OECD, 1997), but still there is lack of research concentrating on the factors for efficient public policy in the developing hybrid venture capital funds for the facilitation of early stage SMEs. Thus the problem of the paper covers the following question: what are the motives, factors and present state of development of hybrid venture capital funds in Lithuania?

The paper focuses on the developing of hybrid venture capital funds in Lithuania, which were forced by the EU JEREMIE initiative. In this paper, hybrid venture capital funds refer to pooled money from private and public sources (European Investment Fund (EIF) and Government's investment) in order to increase venture capital investments in early stage SMEs.

Purpose of the article is to explore motives, factors and the present state of developing hybrid venture capital funds in Lithuania in the context of EU JEREMIE initiative.

The object of the article covers hybrid venture capital funds development in Lithuania.

The objectives of the article are as follows:

1. To reveal the main motives for creation and developing hybrid venture capital funds as the tool to facilitate early stage SMEs.

2. To explore factors influencing the creation and development of hybrid venture capital market.

3. To indentify prerequisites of developing venture capital market and the current state of hybrid venture capital funds in Lithuania.

Research methods cover the comparative analysis of scientific literature, documents and reports as well as statistic data.

The paper is organized in the following manner: first section explores the theoretical background of the paper; section 2 outlines the main factors for developing hybrid venture capital funds and section 3 presents the prerequisites and the current state of venture capital market development in Lithuania, focusing on the JEREMIE initiative. Finally, the paper ends with conclusions.

\section{Theoretical background: motives for the creation and development of hybrid venture capital funds}

Empirical evidences depict that due to its exceptional feature to provide money and value added services, venture capital became an important agent in the US innovation system (Ferrary \& Granovetter, 2009). Financial gap and market imperfection are the main barriers for SMEs development (del-Palacio, Zhang, \& Sole, 2010; Mason \& Harrison, 2003). Financing aspects of SMEs in Lithuania were analyzed by Adekola, Korsakiene and Tvaronaviciene (2008), Adamoniene and Trifonova (2007), Tamosiunas and Lukosius (2009), Daugeliene (2008), and Snieska and Venckuviene (2009, 2010).

The mentioned problem is forced due to the recent recession perspective. Due to economic crisis in many countries lots of investors have lost their ability to cash out their investments, for this reason they are more cautious in investing their money in risky business. For example, Lerner (2010) contends that “(...) financial crisis appears to have had a substantial negative effect on investors' willingness to finance innovative entrepreneurship". Therefore the main motives for the establishment and development of hybrid venture capital funds are to eliminate the existing barriers for early stage SMEs. Recent research report on the impact of publicly financed support schemes on firm performance explores that “'Hybrid' venture capital schemes backed by both private and public sector funding play an increasingly important role in the risk capital funding of early-stage firms with the potential for significant growth" (Nightingale, Murray, Cowling, Baden-Fuller, Mason, Siepel, Hopkins \& Dannreuther, 2009).

The growing number of literature in the field of public venture capital financing programs indicates the importance of Governments' role in enhancing venture capital markets. Small business innovation and research program (SBIR) was scrutinized by Lerner (1999), The Australian Innovation Investment Fund (IIF), which aims to enhance the financing of small high tech companies was analyzed by Cumming (2007), the UK Enterprise investment scheme and Venture capital Trust program were analyzed by Cowling et al. (2008).

According to Florida and Smith (1993), venture capital market does not need help especially from government. They argued that "Federal policy can help stimulate innovation and the growth of high-tech startups - but not by interfering in capital markets“" (Florida \& Smith, 1993). Having in mind that US venture capital investments are the leading ones worldwide, the government intervention should be addressed more cautiously, but in small countries like Baltic States, the venture capital investments are scares, thus the Governments' intervention could enhance venture capital investments in early stage SMEs. Research of 15 EU members' emphasized, that "Larger public participation is correlated with smaller VC industries" (Leleux \& Surlemont, 2003). Recent study prepared by Lerner (2010) analyses the entrepreneurial aspects in the context of current recession and it concludes that " $(. .$.$) the most effective policies are likely those that$ focus on increasing the efficiency of private markets over the long term, rather than providing a short-term funding boost during periods when the market is already active".

The literature review indicates the positive aspects of venture capital market. Nevertheless, the recent actions taken in US towards tightening regulation of private equity firms' showed, that despite positive effects venture capital is also related to lack of transparency, money laundering, etc. Still this aspect in literature is scarcely addressed. Thus, the cautious regulation framework for the implementation of public frameworks towards enhancing venture capital market must be foreseen, in order to get the best expected outcome.

To sum up, various Governments' initiatives around the world seek to enhance the entrepreneurial environment and improve the access to capital for SMEs. Moreover it is the main motive for Government to invest in venture 
capital funds. Despite many scientists interest in Governments' role in the development of venture capital market, there is still a gap in this research scope in terms of factors influencing this process. Thus, the next section will explore the factors for the development of hybrid venture capital markets through the Government's intervention.

\section{Factors for the development of hybrid venture capital market}

Three level factors, which have possible impact on the development of a hybrid venture capital market is discerned and presented further (see Figure 1). Firstly, the venture capital supply-side factors will be presented, and then continued with the venture capital demand-side factors, and finally the macroeconomic factors affecting both venture capital supply and demand will be discussed.

1) Venture capital (VC) supply-side factors. Venture capital supply is the quantity of investors willing to invest in early stage SMEs. The adequate venture capital supply is important factor for driving venture capital funds. The quality of the funds is more important than quantity. For example, Cumming and Johan (2009) emphasized that “(...) impact of government sponsored VC funds depends not only on the design of the program but also on the selection of the VC managers carrying out the investments." (Cumming \& Johan, 2009). Thus, qualified and experienced venture capital funds' managers are important factor as well (Keuschnigg, 2003; Plage, 2006), because this feature is crucial in the ability to raise fund. Additionally to that del-Palacio et al. (2010) contends that along with previous experience of investors the size of investors is important too.

Recent research by Ferrary and Granoveter (2009), focuses on the role of venture capital in the Silicon Valley complex innovation system and it indicates that venture capital acts like the trigger for interaction between agents (like universities, large firms, research laboratories, VC firms, law firms, investment banks, commercial banks certified public accounts, consulting groups, recruitment agencies, public relation and media) in the innovative cluster.

Active participation of venture capitalists in their portfolio companies was emphasized by Keuschnigg (2003) too. 'Active involvement' covers the value added services to a portfolio company in terms of consultation in business development issues, providing business contacts, monitoring (Gompers, 1995), influencing investee's internationalization (Lockett, Wright, Burrows, Scholes, \& Paton, 2008) and professionalization (Hellmann \& Puri, 2002).

Recent study (Nightingale et al., 2009) indicates that profile of a company, the scale of the fund and fixed costs have impact on the return on investment (ROI). For example, smaller investment funds encounter with such problems like less risk diversification across the portfolio companies and high fixed costs (which occur during the screening, selection and contracting period) (Nightingale et al., 2009).

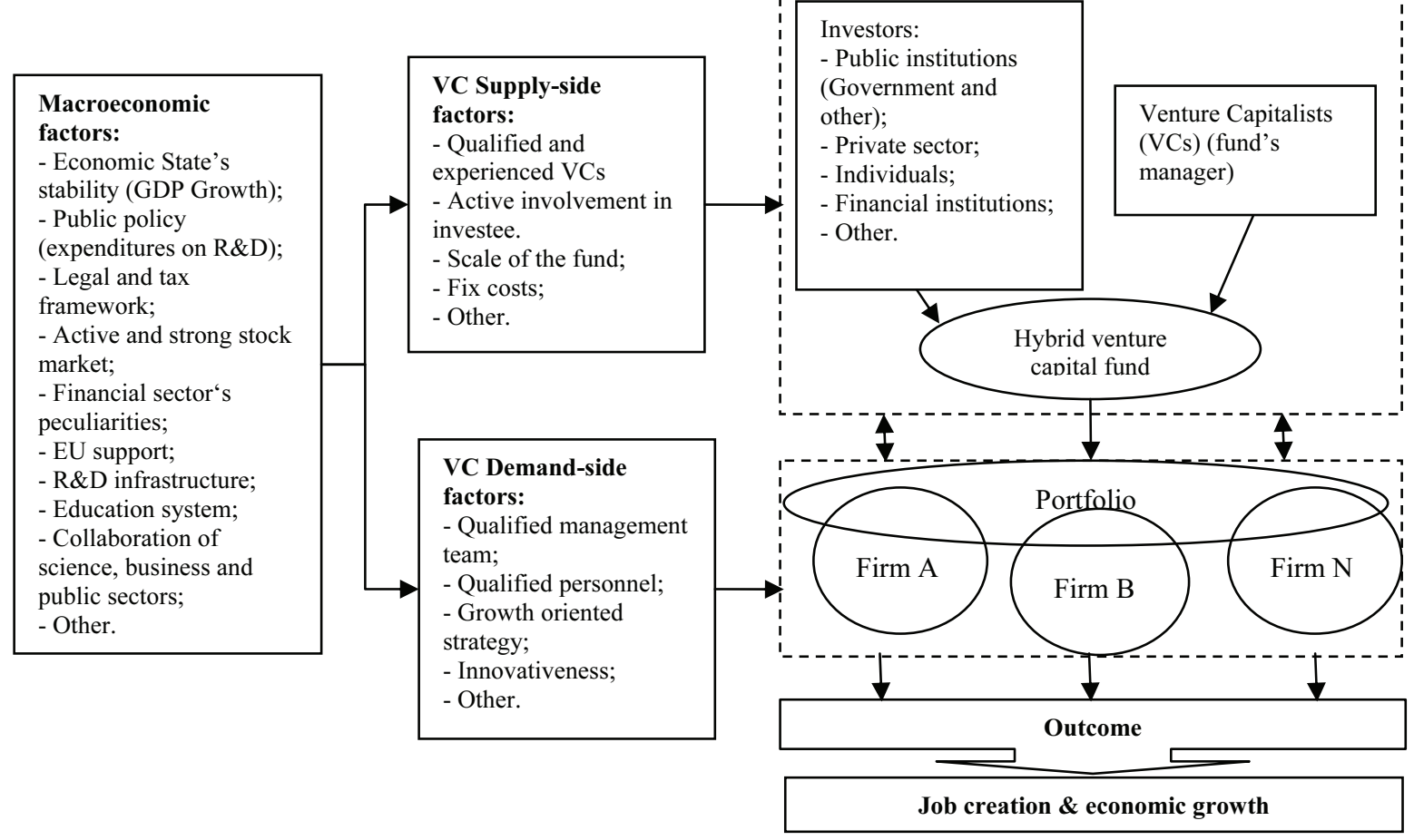

Figure 1. Factors influencing hybrid venture capital funds development

2) Venture capital demand-side factors. In theoretical discourse one of the main factors for the development of active venture capital markets in order to seek the economic benefits is the demand of venture capital (Plage, 2006; Gompers \& Lerner, 1998). The venture capital demand is the number of entrepreneurs willing to acquire venture capital finance. Further, the demand-side factors which have possible influence on the hybrid venture capital funds' success are outlined.

Qualified personnel and qualified management team are important factors for the companies innovation capacity (Hellmann \& Puri, 2002). The 'critical mass' of specialists in venture can spur innovativeness and lead to successful implementation of research and development 
(R\&D) projects. According to Ferrary and Granoveter (2009), the success of venture depends on the 'embeddedness' in complex social networks, not only on the quality and innovativeness of venture. However, 'embeddedness' also depends on ventures management teams' professionalization in terms of communication, keeping contacts and etc.

Recent research indicates that innovativeness of a firm can help to attract venture capital financing (Caselli, Gatti, \& Perrini, 2009), but empirical evidences of 37 Italian venture capital backed firms conclude, that after venture capital investments are made, the firm is not promoted to pursue innovation anymore, they concentrate more on improving financial results (Caselli, et al., 2009).

Growth oriented strategy is important in acquiring external financing. Venture capitalists usually screen business plans and evaluate future development possibilities of venture.

3) Macroeconomic factors. Countries' macroeconomic stability plays significant role for both venture capital supply and demand. Macroeconomic stability is characterized by such indicators like gross domestic product (GDP); employment rate; inflation rate; export and import. High rate of macroeconomic stability encourages investors to invest. For instance, Gompers and Lerner (1998) contend that GDP growth and the increase in $\mathrm{R} \& \mathrm{D}$ expenditures positively influence the venture capital performance.

Public policy towards the creation of entrepreneurial culture through launching various programmes for SMEs, elimination of barriers for business creation and development, increasing expenditures on $R \& D$, and enhancing development of knowledge intensive sector (science and technology parks, incubators and etc.) and improving $\boldsymbol{R} \& \boldsymbol{D}$ infrastructure are essential ones. For instance, Milius (2008) contend that incubators and science and technology parks “(...) enable start-up companies to use their manufacturing and human resources more effectively and continuously develop knowledge-based business". Practical experience of Silicon Valley and "Technopolis Plc" (Finland) indicate that Science and technology parks create favourable environment for business development and are the right place for entrepreneurs and a venture capitalist to meet. The Government role in venture capital market development mainly reveals through legal and tax framework. Empirical evidences by Armour and Cumming (2006) revealed, that legal environment is a very important determinant for venture capital supply and demand, therefore, they conclude that relevant fiscal and legal environments stimulate the establishment of venture capital and private equity funds and boost the supply of capital.

Taxation matters as well for both venture capital supply and demand. "One of the most important factors determining the attractiveness of business environment, is the level of tax burden or, more generally, tax policy." (Kindsfateriene \& Lukasevicius, 2008). The research so far indicated that the reduction in capital gain tax rate resulted in more venture capital funds raised (Gompers \& Lerner, 1998) and early stage and high-tech venture capital investments made (Da Rin, et al., 2006).
Empirical evidences by Black and Gilson (1998) and Jeng and Wells (2000) indicated that the strength of stock market was an important factor for developing venture capital public initiatives as well. As the venture capital investments are risk intensive, thus, the investments' liquidation opportunities become one of the key issue in the venture capital investment process. Many scientists agree that the initial public offering (IPO) is the most successful exit strategy (Suchard, 2009), and an active and strong equity market is a very important factor in the creation venture capital market. The peculiarities of Lithuanian stock market were analyzed by Snieska, Laskiene \& Pekarskiene (2008).

Financial sector's peculiarities. Venture capital is an alternative financial source for financing SMEs, thus, financial market's peculiarities such as cost of banks' loans, availability of microcredit's and others are an important factor as well. It is no doubt that banking sector covers a huge part of debt portfolio in Europe. Adekola et al. (2008) indicated that venture capital market was not the core in financing innovation in Lithuania: "the companies indicated that they finance new projects from their own funds $(67 \%)$ and from the EU funds (28\%).

Among the macroeconomic factors for the creation of venture capital market is availability of $\boldsymbol{E} \boldsymbol{U}$ support. Recent research explores the EU structural funds' effects on various industries (Grundey, 2008; Ginevicius et al. 2008; Ginevicius \& Podvezko, 2009). There are few initiatives in European Union context which aim to facilitate SMEs indirectly through the financial intermediates (European Commission, 2009): EU Competitiveness and Innovation Framework Programme (CIP); G2G focuses on support of innovative entrepreneurs in Europe; European Investment Fund (EIF) venture capital instruments; and EU Structural Funds in terms of JEREMIE initiative.

Effective educational system matters as well in terms of preparing high quality specialists for both venture capital firms and entrepreneurial companies.

To sum up, effective interaction between venture capital supply and demand can result in job creation and economic growth (see Figure 1). The factors discussed above do not encompass all factors, but reflect the factors discussed in a substantial amount of research.

\section{Current state of hybrid venture capital fund's development in Lithuania}

This section will explore the current state of venture capital market performance and activities towards the JEREMIE initiative in Lithuania. A shortage of quantitative and qualitative data in popular as well as in academic literature is the utmost problem in analyzing Lithuanian venture capital market.

Lithuanian venture capital market has already experienced its fifteen years of performance. Nevertheless, the real venture capital investments have taken place recently, because buyouts and later stage business investments have been the leading ones previously. But the situation seems to be changing. Almost for three years banks are very limited in providing loans for companies in Lithuania; therefore the venture capital funds are now 
taking the floor through the EU JEREMIE initiative (Radzeviciute, 2010).

Figure 2 bellow depicts a private equity investment (these data represent aggregate data of an early stage investment, later stage investment and buyouts as well) in three Baltic States (Lithuania - LT; Latvia - LV; Estonia $\mathrm{EE})$. The highest peak of private equity investment was reached in 2007, which was coincident with the boom in European private equity market (mentioned in the Introduction), and in 2008 and 2009 the investments in private equity have significantly reduced.



Figure 2. Private equity investments as a percentage of GDP in Baltic States (data source: EVCA Central and Eastern Europe Task Force $(2008 ; 2010))$

Thus, it is possible that due to EU JEREMIE initiative the investment in private equity particularly in early stage SMEs will improve in upcoming years.

JEREMIE initiative provides financial instruments for SMEs through financial intermediaries (Banks, venture capital firms). The instruments are as follow: microcredit, guarantees, and venture capital and equity type instruments. Important aspect of JEREMIE is the recycling of funds, repayments from financial intermediaries will be invested further (European Investment Fund, 2010). It will set the background for the self sustainable venture capital market in Lithuania.

Implementing JEREMIE initiative debt instruments and equity instruments already have been launched in Lithuania. For the implementation of debt instruments three Banks were selected (AB Šiaulių bankas; AB SEB bankas" and "Swedbank", AB). Total planned amount for these instruments is 294 million Euros (half of this amount will be provided from EIF). For equity instruments in Lithuania three financial intermediaries are selected: BaltCAP, LitCapital and the consortium of "STRATA and MES invest". The first two intermediaries are for the management of venture capital funds, and the latter is for the management of Business Angels Co-investment Fund.

As Table 1 presents, the total amount of 48.4 million Euros is foreseen for equity instruments. The biggest share of money will come from EIF. It is no doubt that with the help of JEREMIE initiative the supply of venture capital for SMEs will increase significantly in Lithuania.

But still the target SMEs should be selected cautiously in order to seek the biggest effect of public initiative. Recently launched fund "Business angels' fund I" by the consortium "STRATA and MES invest" already have made two investments in $U A B$ "ART21" and $U A B$ "Nuostabioji Technologija".

The principal aspect in business angels' investment scheme is the investment in new equity emission, the maximum amount for one company is around 400 thousands Euros (47.5 percent provided by EIF, 2.5 percent provided by fund manager's, and 50 percent by business angel) (Radzeviciute, 2010).

Venture capital instrument has not made any investment yet, but as outlaid in the official internet websites of funds' managers', the business plans evaluation process is started. And few investments will be made soon.

Table 1

\section{Planned amount for the Equity Instruments of JEREMIE} initiative in Lithuania

\begin{tabular}{|l|l|c|}
\hline $\begin{array}{l}\text { Funds' } \\
\text { Name }\end{array}$ & Equity Instruments & Million EUR \\
\hline \multicolumn{1}{|c|}{ 1) Venture capital instrument } & \\
\hline $\begin{array}{l}\text { Lithuania } \\
\text { SME Fund }\end{array}$ & $\begin{array}{l}\text { BaltCap (Fund's manager) and } \\
\text { other sources }\end{array}$ & 6 \\
\cline { 2 - 3 } & EIF (JEREMIE Holding Fund) & 14 \\
\hline $\begin{array}{l}\text { LitCapital } \\
\text { fund }\end{array}$ & $\begin{array}{l}\text { LitCapital (fund's manager) and } \\
\text { other sources }\end{array}$ & 6 \\
\cline { 2 - 4 } & EIF (JEREMIE Holding Fund) & 14 \\
\hline \multicolumn{2}{|c|}{ Business angels investments } & \\
\hline $\begin{array}{l}\text { Business } \\
\text { angels' } \\
\text { fund I }\end{array}$ & \begin{tabular}{l} 
Business Angels Co-investment \\
\hline \multicolumn{2}{|l|}{ Fund (manager Consortium of }
\end{tabular} \\
\hline & STRATA and MES invest) & 8.4 \\
\hline
\end{tabular}

To sum up, the venture capital market in Lithuania is in the infant stage and to talk about the present effect on the economy is too early. Secondly, the Government's role and the EU support in developing a venture capital market is huge, but as literature review revealed it should be just an initiator and not the main actor.

\section{Conclusions}

The literature review shows the importance of venture capital market in boosting region's economy in terms of financing new prospective ventures. In the perspective of recent economic recession the financial gap for SMEs is even bigger. Thus, the vitality of the venture capital markets could be increased by initiating hybrid venture capital funds, where governments' and private investments are pooled in order to finance early stage business.

Recent researches emphasize that the main motives for the creation of hybrid venture capital funds are to increase investments in early stage SMEs in order to fill the financial gap and overcome market imperfection. Substantial amount of research highlighted that public programs for the inspiration of a venture capital market in order to provide capital for SMEs, must satisfy clearly the target SMEs seeking to overcome the competition problems in the market.

The model presented in the paper revealed that three level factors which have possible influence on the development of hybrid venture capital funds' are: venture capital demand-side factors; supply-side factors and macroeconomic factors.

To sum up, few common implications for Lithuania and other Baltic States countries must be made. Government's role in developing venture capital market is huge, but as literature revealed it should be just an initiator and not the main actor and the regulation towards venture 
Vytautas Snieska, Vitalija Venckuviene. Hybrid Venture Capital Funds in Lithuania: Motives, Factors and...

capital market should be taken into account, because despite positive effects of venture capital market on economy, there are negative aspects as well, for example, money laundering, lack of transparency and etc. However, this negative aspect in literature is very scarcely addressed.

\section{References}

Adamoniene, R., \& Trifonova, J. (2007). The State Support for small and Medium Sized Companies: General and Practical Aspects of Lithuania. Inzinerine Ekonomika-Engineering Economics(1), 16-21

Adekola, A., Korsakiene, R., \& Tvaronaviciene, M. (2008). Approach to Innovative Activities by Lithuanian Companies in the Current Conditions of Development. Technological and Economic Development of Economy, 14(4), 595-611.

Armour, J., \& Cumming, D.(2006). The Legislative Road to Silicon Valley. Oxford Economic Papers, 58, $596-635$.

Black, B. S., \& Gilson, R. J. (1998). Venture Capital and the Structure of Capital Markets: Banks Versus Stock Markets. Journal of Financial Economics, 47(3), 243-277.

Bottazzi, L., \& Da Rin, M. (2002, Nov 22-23). Financing entrepreneurial firms in Europe: Facts, issues, and research agenda. Paper presented at the Workshop on Venture Capital, Entrepreneurship and Public Policy, Munich, Germany.

Caselli, S., Gatti, S., \& Perrini, F. (2009). Are Venture Capitalists a Catalyst for Innovation ? European Financial Management, 15(1), 92-111.

Cowling, M., Bates, P., Jagger, N., \& Murray, G. (2008). Study of the impact of the Enterprise Investment Scheme (EIS) and Venture Capital Trusts (VCTs) on company performance. HM Revenue \& Customs Research Report 44, Institute for Employment Studies. Retrieved from http://www.hmrc.gov.uk/research/report44.pdf

Cumming, D. (2007). Government policy towards entrepreneurial finance: Innovation investment funds. Journal of Business Venturing, 22(2), 193-235.

Cumming, D., \& Johan, S. (2009). Pre-seed government venture capital funds. Journal of International Entrepreneurship, 7(1), 26-56.

Da Rin, M., Nicodano, G., \& Sembenelli, A. (2006). Public policy and the creation of active venture capital markets. Journal of Public Economics, 90(8-9), 1699-1723.

Daugeliene, R. (2008). The Streamline of Research and Experimental Development's Infrastructure in Lithuanian National Innovation System. Inzinerine Ekonomika-Engineering Economics(2), 61-69.

del-Palacio, I., Zhang, X., \& Sole, F. (2010). The capital gap for small technology companies: public venture capital to the rescue? Small Business Economics, 1-19.

European Investment Fund. (2010). JEREMIE - Joint European Resources for Micro to Medium Enterprises. Retrieved from http://www.eif.org/jeremie/

European Commission, Enterprise an Industry Directorate General. European Union Support: Programmes for SMEs, 2009: An overview of the main funding opportunities available to European SMEs. Retrieved from http://www.google.lt/url?sa=t\&source=web\&cd=4\&ved=0CCoQFjAD\&url=http $\% 3 \mathrm{~A} \% 2 \mathrm{~F} \% 2 \mathrm{Fec}$. europa.eu $\% 2 \mathrm{Fenter}$ prise $\% 2$ Fnewsroom $\% 2 \mathrm{Fcf} \% 2 \mathrm{~F}$ getdocument.cfm $\% 3 \mathrm{Fdoc}$ id $\% 3 \mathrm{D} 4619 \& \mathrm{rct}=\mathrm{j} \& \mathrm{q}=$ European $\% 20$ Union $\% 20$ Support $\% 3 \mathrm{~A} \% 20$ Programmes $\% 20$ for $\% 20$ SMEs $\% 2 \mathrm{C} \% 202009 \% 3 \mathrm{~A} \% 20 \mathrm{An} \% 20$ overview $\% 20$ of $\% 20$ the $\% 20$ main $\% 20$ fundin g\%20opportunities\%20available\%20to\%20European\%20SMEs.\&ei=ZFS4TJHgKIGDOob6jOMM\&usg=AFQjCNH vHZ2u3FgO53f9k50otJTf_DrJpg\&sig2=Oewo-hiER073274CK2Phvg

EVCA Central and Eastern Europe Task Force (2010).Central and Eastern Europe Statistics 2009: An EVCA Special paper - July 2010. Retrieved from www.evca.eu/WorkArea/linkit.aspx?LinkIdentifier=id\&ItemID=5774

EVCA Central and Eastern Europe Task Force (2008). Central and Eastern Europe Statistics 2007: An EVCA Special paper - September 2008. Retrieved from http://www.slovca.sk/docs/CEE_statistics_2007.pdf

Ferrary, M., \& Granovetter, M. (2009). The role of venture capital firms in Silicon Valley's complex innovation network. Economy and Society, 38(2), 326-359.

Florida, R., \& Smith, D. F. (1993). Keep tThe Government out of Venture Capital. Issues in Science and Technology, 9(4), 61-68.

Ginevicius, R., \& Podvezko, V. (2009). Evaluating the Changes in Economic and Social Development of Lithuanian Counties by Multiple Criteria Methods. Technological and Economic Development of Economy, 15(3), 418-436.

Ginevicius, R., Podvezko, V., \& Bruzge, S. (2008). Evaluating the Effect of State Aid to Business by Multicriteria Methods. Journal of Business Economics and Management, 9(3), 167-180.

Gompers, P. A. (1995). Optimal Investment, Monitoring, and the Staging of Venture Capital. Journal of Finance, 50(5), 1461-1489.

Gompers, P. A., \& Lerner, J. (1998, Jun 19-20). What drives venture capital fundraising. Paper presented at the 12th Meeting of the Brookings Microeconomics Panel, Washington, D.C.

Grundey, D. (2008). Sustainable Energy Projects in Lithuania for Promoting Regional Development. Transformations in Business \& Economics, 7(3), 129-162.

Hellmann, T., \& Puri, M. (2002). Venture capital and the professionalization of start-up firms: Empirical evidence. Journal of Finance, 57(1), 169-197.

Jeng, L. A., \& Wells, P. C. (2000). The determinants of venture capital funding: evidence across countries. Journal of Corporate Finance, 6(3), 241-289. 
Jääskeläinen, M., Maula, M., \& Murray, G. (2007). Profit distribution and compensation structures in publicly and privately funded hybrid venture capital funds. Research Policy, 36(7), 913-929.

Keuschnigg, Ch. (2003). Optimal Public Policy for Venture Capital Backed Innovation. IFF-HSG, CEPR and CESifo, University of St. Gallen, Department of Economics, Discussion paper no. 2003-09. Retrieved from http://www.vwa.unisg.ch/RePEc/usg/dp2003/dp0309keuschnigg_ganz.pdf

Kindsfateriene, K., \& Lukasevicius, K. (2008). The Impact of the Tax System on Business Environment. Inzinerine Ekonomika-Engineering Economics(2), 70-77.

Leleux, B., \& Surlemont, B. (2003). Public versus private venture capital: seeding or crowding out? A pan-European analysis. Journal of Business Venturing, 18(1), 81-104.

Lerner, J. (1999). The government as venture capitalist: The long-run impact of the SBIR program. Journal of Business, $72(3), 285-318$.

Lerner, J. (2001, Apr). When bureaucrats meet entrepreneurs: The design of effective "public venture capital" programs. Paper presented at the Conference on Public Policy and the Economics of Entrepreneurship, Syracuse, NY.

Lerner, J. (2010). Innovation, Entrepreneurship and Financial Market Cycles, OECD Science, Technology and Industry Working Papers, 2010/3, OECD Publishing.

Lockett, A., Wright, M., Burrows, A., Scholes, L., \& Paton, D. (2008). The export intensity of venture capital backed companies. Small Business Economics, 31(1), 39-58.

Mason, C., \& Harrison, R. (2003). Closing the regional equity gap? A critique of the Department of Trade and Industry's regional venture capital funds initiative. Regional Studies, 37(8), 855-868.

Milius, P. B. (2008). Ten Years In The System of Entrepreneurship Stimulation. Inzinerine Ekonomika-Engineering Economics(4), 42-45.

Nightingale, P., Murray, G., Cowling, M., Baden-Fuller, Ch., Mason, C., Siepel, J., Hopkins, M., \& Dannreuther, Ch. (2009 September). From funding gaps to thin markets: UK Government support for early-stage venture capital. NESTA and BVCA, Retrieved from: http://www.nesta.org.uk/library/documents/Thin-Markets-v9.pdf

Organisation for Economic Co-operation and Development (1997). Government Venture Capital for Technology-Based Firms. OCDE/GD(97)201. Retrieved from OECD Directorate for Science, Technology and Industry: http://www.oecd.org/LongAbstract/0,3425,en_2649 34273_2093641_1_1_1_1,00.html

Plage, A. (2006). Public Policy for Venture Capital: A comparison of the United States and Germany. Deutscher Universitats-Verlag.

PEREP Analytics ${ }^{\mathrm{TM}}$ (2010). EVCA Quarterly Activity Indicator: Q1 2007 - Q2 2010. Retrieved from www.evca.eu/ WorkArea/linkit.aspx?LinkIdentifier=id\&ItemID=5888

Radzeviciute, A. (2010). Verslo angelai. VALSTYBË: ekonomika ir politika, tendencijos ir perspektyvos, 7 (39), $46-51$.

Sahlman, W. A. (1990, Mar 30-31). The Structure and Governance of Venture-Capital Organizations. Paper presented at the Conf on the Structure and Governance of Enterprise, Boston, Ma.

Snieska, V., Laskiene, D., \& Pekarskiene, I. (2008). Stock returns and the macroeconomic environment: The case of the Vilnius stock exchange. Transformations in Business \& Economics, 7(2), 115-129.

Snieska, V., \& Venckuviene, V. (2009). Venture Capital Impact on the Region's Competitiveness. Economics \& Management, 961-967.

Snieska, V., \& Venckuviene, V. (2010). Peculiarities of venture capital in financing the early stage business in Lithuania. In Selected papers of the 6th International Scientific Conference "Business and Management-2010", Vilnius: Technika, 1(13), 207-214.

Suchard, J. A. (2009). The impact of venture capital backing on the corporate governance of Australian initial public offerings. Journal of Banking \& Finance, 33(4), 765-774.

Tamosiunas, T., \& Lukosius, S. (2009). Possibilities for Business Enterprise Support. Inzinerine Ekonomika-Engineering Economics(1), 58-64.

Vytautas Snieška, Vitalija Venckuvienè

Mišrūs rizikos kapitalo fondai Lietuvoje: motyvai, veiksniai ir esama plètojimosi stadija

Santrauka

Daugelis mokslininkų pripažissta mažų ir vidutinių įmonių (MVI) didelę reikšmę ekonomikai. Atlikti tyrimai parodė, kad finansavimo stoka - tai pagrindinė problema, su kuria susiduria MVI ankstyvajame plètros etape (del-Palacio, et al., 2010; Mason ir Harrison, 2003). Kadangi jaunos ir perspektyvios i̇monès neturi ilgalaikès veiklos rezultatų, dažnai susiduria su apyvartinių lèšu trukumu ir neturi pakankamai turto, kad galètų naudoti kaip užstatą bankui, šiuo atveju papildomą kapitalą gali pritraukti iš rizikos kapitalistų (privačių investuotojų arba rizikos kapitalo fondų). Mokslininkai akcentuoja ypatingą rizikos kapitalo reikšmę ne tik finansuojant perspektyvias pradžios įmones, bet ir suteikiant nepakeičiamas pridètinès vertès paslaugas (konsultacijas verslo plètojimo, produkto plètojimo ir kt. klausimais). Naujausi tyrimai rizikos kapitalo srityje - analizuojama šio sektoriaus teikiama pridėtinè vertè portfelio įmonei: rizikos kapitalo įtaka įmonès profesionalizacijai (Hellmann ir Puri, 2002), rizikos kapitalo įtaką įmonės internacionalizacijai (Lockett et al. 2008); rizikos kapitalo kaip katalizatoriaus vaidmuo inovacijų kūrimui (Caselli et al. 2009).

Rizikos kapitalo moksliniame diskurse labiau diskutuojama apie teigiamą rizikos kapitalo poveiki tiek mikroekonominiu, tiek makroekonominiu aspektu. Ypač akcentuojamas jo vaidmuo finansuojant smulkuji ir vidutini verslą ankstyvajame etape, taip pat dažnai siejamas su inovacijų skatinimu, darbo vietų kūrimu bei ekonomikos augimu. Dẻl šių priežasčių rizikos kapitalo rinkos aktyvinimas vis labiau tampa atskirų šalių prioritetu skatinant ekonomikos augimą. Vyriausybès, tiesiogiai investuodamos i rizikos kapitalo fondus ir siekdamos padidinti rizikos kapitalo investicijas i ankstyvojo etapo MVI, gali palengvinti i̇monèms gauti finansavimą. Ši problema ypač reikšminga esant 2007 m. krizei, kai bankai sugriežtino paskolu išdavimo sąlygas. 2007 m. JAV prasidèjusi nekilnojamo turto krizė išplito visame pasaulyje ir gerokai paveikė visas gyvenimo sritis. Ypač nuo jos nukentėjo 
Vytautas Snieska, Vitalija Venckuviene. Hybrid Venture Capital Funds in Lithuania: Motives, Factors and...

finansinis sektorius, kartu ir rizikos kapitalo sektorius. Daugelis rizikos kapitalo investicijų tapo nelikvidžios, o tai salygojo pasyvumo rizikos kapitalo rinkoje atsiradima. Bankai ir kiti finansiniai tarpininkai, patyrę didelių nuostolių, pasyviai investuoja i̇ ankstyvojo etapo MVİ (Lerner, 2010). Mišrius rizikos kapitalo fondus tyrinèjo Leleux ir Surlemont (2003) ir OECD (1997). Rizikos kapitalo fondai, i kuri tiesiogiai investuoja Vyriausybé ir kiti privatūs bei instituciniai investuotojai, siekdami padidinti investicijas į ankstyvojo etapo MVİ, yra vadinami mišrūs rizikos kapitalo fondai (OECD, 1997). Lietuvoje rizikos kapitalo rinka labai maža ir, palyginti su pasauline praktika, labai jauna. Mišrūs rizikos kapitalo fondai Lietuvoje pradèti formuoti visai neseniai naudojant Europos Sajungos struktūrinius fondus. Europos Komisijos ir Europos centrinio banko bendra iniciatyva JEREMIE (Jungtiniai Europos ištekliai vidutinèms ir mikroimonèms) - tai galimybè, naudojant Europos Sajungos struktūrinių fondų paramą, dali lèšų skirti finansinėms priemonėms - rizikos kapitalui, garantijoms ir paskoloms, taip palengvinant MVİ priejjimą prie kapitalo.

Atlikti tyrimai parode, kad daugelis mokslininku analizuoja vyriausybines programas (Keuschnigg, 2003; Plage, 2006), kurios skatina rizikos kapitalo rinkos plètra. Šio straipsnio tikslas - ištirti mišrių rizikos kapitalo fondų steigimo motyvus, veiksnius ir pasekmes Lietuvoje. Objektas - mišrūs rizikos kapitalo fondai Lietuvoje. Iškelti šie uždaviniai: 1) atskleisti pagrindinius mišrių rizikos kapitalo fondų steigimo ir plètojimo motyvus, siekiant sukurti palankią aplinką MVİ; 2) ištirti veiksnius, sąlygojančius mišrių rizikos kapitalo fondų veiklą; 3) identifikuoti sąlygas ir dabartinę rizikos kapitalo rinkos plètros stadiją Lietuvoje JEREMIE iniciatyvos kontekste.

Atlikti tyrimai parodè, kad pagrindinės kliūtys, su kuriomis susiduria smulkios ir vidutinės įmonès ankstyvajame plètros etape, yra šios: finansavimo stoka ir rinkos netobulumas (del-Palacio, et al., 2010; Mason ir Harrison, 2003). Todèl pagrindiniai mišrių rizikos kapitalo fondų motyvai - panaikinti šias kliūtis verslui, sudarant sąlygas lengviau gauti finansavimą ankstyvajame plètros etape, ir taip sušvelninant rinkos konkurencija.

Atlikus rizikos kapitalo rinkos plètrą sąlygojančiu veiksnių analizę, šie veiksniai buvo suskirstyti ị tris grupes: rizikos kapitalo pasiūlai darantys itaką veiksniai; rizikos kapitalo paklausai darantys itaką veiksniai; makroekonominiai veiksniai, kurie turi itakos šioms dviem veiksnių grupėms. Remiantis literatūros analize, rizikos kapitalo pasiūlos (investuotojai norintys ir galintys investuoti į naujas, ankstyvojo plètros etapo inovatyvias ịmones) veiksniai yra šie: adekvati rizikos kapitalo fondu pasiūla (Plage, 2006), kvalifikuoti ir turintys patirties rizikos kapitalo fondu valdytojai (Keuschnigg, 2003; Plage, 2006), fondo dydis (del-Palacio et al., 2010) bei investuotojo aktyvus dalyvavimas portfelio imonès valdyme (Keuschnigg, 2003), antrepreniškų i̇moniu pasiūla, fiksuotos sąnaudos (Nightingale et al., 2009).Rizikos kapitalo paklausos (įmonès, norinčios gauti rizikos kapitalo finansavima) veiksniai yra šie: rizikos kapitalo paklausa (Plage, 2006; Gompers ir Lerner, 1998), kvalifikuota vadovų komanda ir kvalifikuotas įmonės personalas (Hellmann ir Puri, 2002), portfelio ¿̨monès inovatyvumas (Caselli et al. 2009), augimui skirta ịmonès strategija. Makroekonominiai veiksniai daro itaką tiek rizikos kapitalo paklausos, tiek pasiūlos susiformavimui. Remiantis atliktais tyrimais, galima išskirti šiuos makroekonominius veiksnius: makroekonominis šalies stabilumas, viešosios politikos keliami tikslai, kuriant antreprenišką kultūrą šalyje, teisine ir mokestinè aplinka (Armour ir Cumming, 2006); aktyvi ir stipri akcijų rinka (Black ir Gilson, 1998; Jeng ir Wells, 2000); finansinio sektoriaus ypatumai, efektyvi švietimo sistema ir struktūrinè Europos Sajungos parama.

Rizikos kapitalo rinka Lietuvoje tik pradeda formuotis. Lietuvoje veikia sąlyginai nedaug rizikos kapitalo įmonių. Populiariausia finansinė MVI priemonè Lietuvoje- paskola iš banko. Gal dèl to rizikos kapitalo rinka ir nėra didelè Lietuvoje. Tačiau dabartinè ekonominè krizė šiek tiek pakoregavo finansinès rinkos „,tradicijas”. Kadangi bankai prasidejjus recesijai sugriežtino paskolų išdavimą juolab rizikingoms, jaunoms MVIt, rizikos kapitalui atsirado didesnè paklausa (Radzevičiūtè, 2010). Nors ir šiuo atveju rizikos kapitalas yra atsargesnis, ieško labiau likvidžių investicijų. EVCA duomenimis (EVCA Central and Eastern Europe Task Force, 2008; 2010), nuo 2007 m. investicijos i̇ privatų kapitalą Baltijos šalyse gerokai sumažèjo. Šią situaciją turètų ištaisyti neseniai pradèta JEREMIE iniciatyva, kuri apima ne tik Lietuvą, bet ir kitas Europos Sajungos šalis: Latvija, Estija, Vengrija, kai kuriuos Italijos ir Prancūzijos regionus. JEREMIE iniciatyva Lietuvoje apima tris priemones: 1) paskolu priemone (paskolas teikia trys atrinkti bankai - AB SEB bankas, AB Šiaulių bankas ir „Swedbank“, AB); 2) rizikos kapitalo fondai. Sudarytos sutartys su 2 kapitalo valdymo bendrovėmis „LitCapital“ ir „BaltCap“. Maksimali investicija i vieną imonę gali siekti iki $10 \mathrm{mln}$. Lt; 3) bendrai su verslo angelais investuojantis fondas (,verslo angelų fondas“), fondą administruoja konsorciumas „STRATA ir Mes Invest“. Šių metų pradžioje pradėjęs veikti „Verslo angelų fondas I” iki šiol yra investavęs i dvi ̨̇monès: UAB „ART21“ ir UAB „Nuostabioji technologija“. Šio fondo veikimo principas yra toks: fondas investuoja kartu su verslo angelu (privatus investuotojas, investuojantis nuosavas lěšas). Taigi 47,5 proc. investiciju sumos suteikia EIF, 2,5 proc. - fondo valdytojas ir 50 proc. finansuoja verslo angelas. Investuojama ị naujai išleistą akcijų emisija, vienai įmonei maksimali suma yra 400000 eurų. Be to, verslo angelas ịsipareigoja bent vieną dieną dirbti investuojamojoje įmonejje (Radzevičiūtė, 2010). Rizikos kapitalo srityje vykdoma perspektyvių verslo planų investicijoms paieška.

Taigi, remiantis atliktais tyrimais, galima teigti, kad rizikos kapitalo sektorius gerokai prisideda prie jaunų ir perspektyvių MVI finansavimo. Siekiant labiau investuoti ị MVỊ formuojami mišrūs rizikos kapitalo fondai, $\mathfrak{i}$ kuriuos investuoja Vyriausybè ir kiti privatūs bei instituciniai investuotojai. Tačiau reikia nepamiršti, kad rizikos kapitalo investuotojai siekia naudos sau. Todell reikalingas adekvatus šios rinkos reguliavimo mechanizmas, kad būtų išvengta neskaidrių sandorių ar kitų „,̌ešèlinių“ veiksmų, kurie gali sąlygoti didelius neigiamus pokyčius ekonomikoje.

Raktažodžiai: Mišrus rizikos kapitalo fondas, maža ir vidutine immone, Europos Sajungos parama, JEREMIE iniciatyva.

The article has been reviewed.

Received in November, 2010; accepted in February, 2011. 